\title{
Supply Chain Management Maturity: A Comprehensive Framework Proposal from Literature Review and Case Studies
}

\author{
Guilherme Frederico ${ }^{1}$ \\ ${ }^{1}$ School of Management, Federal University of Paraná - UFPR, Curitiba, Brazil \\ Correspondence: Guilherme Frederico, Prefeito Lothario Meissner, 632, 2o.floor, Jardim Botânico, School of \\ Management, Federal University of Paraná - UFPR, Curitiba, PR., Postal Code: 80210-170, Brazil. E-mail: \\ guilherme.frederico@ufpr.br
}

Received: October 31, 2016

Accepted: November 25, $2016 \quad$ Online Published: December 8, 2016

doi:10.5539/ibr.v10n1p68

URL: http://dx.doi.org/10.5539/ibr.v10n1p68

\begin{abstract}
Supply chains have an important role in the competition on the current market. The understanding of maturity and its dimensions in terms of supply chain management - SCM can lead companies to better levels of performance. This paper aims to present findings on supply chain management maturity showing a theoretical model developed from the literature review and its application on three case studies. A systematic approach was used to the literature review. Due to the lack in the literature related to the purpose of this paper a long period was considered for the search of references linked to maturity of supply chain management. The approaches for SCM maturity proposed on the literature suggest different e common dimensions which drive a maturity of SCM. These dimensions can be consolidated in eleven key-dimensions of maturity for SCM. Also, it is possible to verify that as the maturity of SCM evolves to an advanced level more integrated and capable a supply chain becomes. The application of this theoretical model through case studies could confirm the framework proposed and generated new directions of research. The theoretical model was applied in three case studies from different segment of industry and with different level of maturity. A qualitative approach was more adequate for this initial step aligned with this exploratory purpose. More qualitative and quantitative studies need to be done to obtain more evidences from the field and from other different segment of industry. This theoretical model is unique taking into consideration that it was developed from various perspectives of maturity proposed on the literature. This same structure can be applied in more field researches seeking better understandings about maturity of SCM. Also, it can be used by practitioners with the purpose to get a better view of SCM maturity dimensions and allow establishing new directions in terms of supply chain decisions.
\end{abstract}

Keywords: maturity, supply chain management, theoretical model, case studies

\section{Introduction}

Nowadays, market competition does not involve only two or more companies anymore. Actually, it occurs between supply chains which compete with each other (Christopher, 2005; Lambert and Cooper, 2000). In order to be more competitive, the focus of supply chain management (SCM) should be cooperation and trust. It is important to achieve a level of performance in the entire supply chain that is more than the sum of performance of each company in the supply chain (Christopher, 2005). Supply chain management practices can evolve over time in any supply chain. A practice can be improved and/or new practices can be implemented. These practices can be grouped in dimensions which can evolve over time characterizing SCM maturity levels. No comprehensive approach to SCM maturity was found in the literature review. Different authors propose different dimensions or levels.

The possible synergies between the companies, members of same supply chain, require the development of new theories, frameworks, methods, and techniques. Those can help the supply chains managers to overcome the challenge of managing the complexity created by the network of companies (Christopher, 2005, Lambert and Cooper, 2000; Chan et al., 2003; Simchi-Levi, Kaminski \& Simchi-Levi, 2003; Ayers \& Malmberg, 2002). Therefore, the correct understanding of SCM maturity dimensions can help practitioners have better understanding of decisions and actions in terms of SCM that must be taken in place. This also can lead managers to be more assertive and effective to achieve a superior supply chain performance.

This paper aims to present the findings from the literature review showing a comprehensive framework with 
dimensions of maturity for SCM. This framework is used as the basis for the multiple case study method application seeking more findings from the empirical perspective. Therefore, the research question which this study aims to answer is: Which are the key dimensions that drive the maturity of SCM?

This research question will guide the literature review as well as the field research. This paper focus on the first step of the research, presenting a literature review built based on a systematic approach. This literature review was the basis to the theoretical model developed for SCM maturity. This framework was the basis for the field research to seek more empirical findings linked to the research question. The second step of the paper focus on presentation of multiple case studies showing the results obtained from the research method applied.

This paper is structured as follows. The next section presents the literature review method and findings. The following section presents the theoretical framework for SCM maturity. After that, findings from the case studies are presented. Finally, final remarks and future directions are considered closing this paper.

\section{Systematic Literature Review Method}

The literature review process followed a systematic approach (Tranfield, Denyer \& Palminder, 2003). Management research is a relatively young field and needs more structure and systematic process to allow a better support with regards the research question which is aimed to answer in a management field research (Tranfield, Denyer \& Palminder, 2003).

More replicability and traceability of the arguments and conclusions using a systematic has been being required in the SCM researches (Seurin \& Gold, 2011). According to Tranfield, Denyer and Palminder (2003), the systematic review basically follows three steps: Planning, Conduction; and Reporting and Dissemination.

In the step planning the plan of literature review is developed and a review protocol is built to seek a detailed guide for the next step which the literature review process will be conducted. With regards to step conduction activities as research identification, selection of studies, assessment of the sources, data extraction and data synthesis are involved.

This paper will focus on the two first steps, 1 and 2 which aim to build a basis for the field research that will be conducted in the future.

The planning of the literature review considered as a basis the central themes of the study: supply chain management and maturity. Into these two main topics the research concentrated on searching for sources related to these two topics.

A period of searching was established considering publications since 1990s until 2012. The long period is justified by the few studies available related to these topics. Also, the study aimed to show the evolution of the theories and models over the time.

Important to emphasize the difficulty faced to find a significant number of publications related to the thematic proposed by this research. Thus, this fact highlights the lack of approaches related to SCM maturity and leverages the originality essence of this study which seeks to bring more clarifications for the research question here considered.

\section{Findings from Literature Review}

In this section the results of the extensive literature review about maturity and maturity of supply chain management will be presented.

Maturity is defined as the stage achieved in a process which it is better developed on its more advanced stage (Oxford, 2011). Maturity frameworks are not new in the management field. Several frameworks have been proposed in literature such as for project management (Kwak and Ibbs, 2002), virtual organizations (Venkatraman \& Henderson, 1998), and product development (Harter, Kishnan \& Salughter, 2000), Performance Measurement Systems (Wettstein \& Kueng, 2002; Van Aken et al., 2005). With regards to supply chain management, six frameworks were found in the literature survey. They are presented in Table 1.

As shown in Table 1, the framework proposed by Lockamy and MacCormak (2004) considers more dimensions than the other five frameworks. Hence, this framework will be foundation for the development of the theoretical model in this study. Additionally, the missing dimensions in Lockamy and MacCormak (2004) framework will be added into this framework in order to have a more robust set of dimensions. 
Table 1. Characteristics of maturity for supply chain management

\begin{tabular}{|c|c|}
\hline Authors & Characteristics \\
\hline Stevens (1989) & $\begin{array}{l}\text { Inventory level, organizational boundaries, customer focus, supply chain costs, planning, visibility and } \\
\text { on-demand orientation, strategic focus, partnership and collaboration, responsiveness, information } \\
\text { technology and control systems, and information share. }\end{array}$ \\
\hline $\begin{array}{l}\text { Ayers and } \\
\text { Malmberg (2002) }\end{array}$ & $\begin{array}{l}\text { Supply chain costs, planning, strategic focus, partnership and collaboration, supply chain management } \\
\text { philosophy, project management, formalization and structuration of processes, integration of processes, } \\
\text { information technology and control systems, information share, and gains share. }\end{array}$ \\
\hline PMG (2007) & $\begin{array}{l}\text { Organizational boundaries, planning, strategic focus, partnership and collaboration, responsiveness, } \\
\text { formalization and structuration of processes, integration of processes, information technology and control } \\
\text { systems, and performance measurement. }\end{array}$ \\
\hline $\begin{array}{l}\text { Lockamy and } \\
\text { McCormak } \\
(2004)\end{array}$ & $\begin{array}{l}\text { Organizational boundaries, customer focus, customer satisfaction, supply chain costs, planning, strategic } \\
\text { focus, partnership and collaboration, structured processes, integration of processes, information } \\
\text { technology and control systems, information and gains share, and performance measurement and } \\
\text { competitiveness as a differentiation. }\end{array}$ \\
\hline $\begin{array}{l}\text { Daozhi et al. } \\
\text { (2006) }\end{array}$ & $\begin{array}{l}\text { Supply chain costs, partnership and collaboration, responsiveness, risk management, information share, } \\
\text { resources share, regulation and incentives in the chain, and resources used in the chain. }\end{array}$ \\
\hline Oliveira (2009) & $\begin{array}{l}\text { Customer focus, customer satisfaction, planning, visibility and on-demand orientation, strategic focus, } \\
\text { partnership and collaboration, responsiveness, formalization and structuration of processes, integration of } \\
\text { processes, information technology and control systems, information share and performance measurement. }\end{array}$ \\
\hline $\begin{array}{l}\text { Reyes and } \\
\text { Giaghetti (2010) }\end{array}$ & $\begin{array}{l}\text { Customer Relationship Management, Performance Measurement Systems, Inventory Management, } \\
\text { Collaboration, Process Management, Information Systems and Technology, Integration of Processes, } \\
\text { Risk and Project Management, human Resources Management }\end{array}$ \\
\hline \multicolumn{2}{|c|}{$\begin{array}{l}\text { There are other publications related to maturity in supply chain management which the authors in fact don't } \\
\text { present a framework with dimensions and characteristics of maturity levels but use a maturity model already } \\
\text { proposed to verify or test the model in any specific research object as in Childerhouse et al. (2011), Netland and } \\
\text { Alfnes (2011), Aryee, Naim and Lalwani (2008), McCormak, Ladeira and Oliveira (2008), Huang and Handfield } \\
\text { (2015), Okongwu, Morimoto and Lauras (2013), Dellana and Kros (2013), Souza, Guerreiro and Oliveira } \\
(2015)\end{array}$} \\
\hline
\end{tabular}

\section{Theoretical Framework for SCM Maturity}

In this section, the theoretical model for SCM maturity will be presented based on the findings from the literature review which were the basis to build the constructs of this research. The framework was developed using the following steps:

- Identification of the dimensions of SCM maturity;

- Identification of the characteristics of each dimension for each level of maturity

- Alignment between dimensions characteristics and level of maturity.

Table 2. Dimensions of maturity for supply chain management considered by authors

\begin{tabular}{|c|c|c|c|c|c|c|c|}
\hline $\begin{array}{l}\text { Maturity } \\
\text { Dimensions }\end{array}$ & $\begin{array}{l}\text { Stevens } \\
\text { (1989) }\end{array}$ & $\begin{array}{ll}\text { Ayers } & \text { and } \\
\text { Malmberg } & \\
(\mathbf{2 0 0 2}) & \end{array}$ & $\begin{array}{l}\text { Lockamy and } \\
\text { McComack } \\
\text { (2004) }\end{array}$ & $\begin{array}{l}\text { PMG } \\
\text { (2007) }\end{array}$ & $\begin{array}{l}\text { Daozhi et. } \\
\text { al. (2006) }\end{array}$ & $\begin{array}{l}\text { Oliveira } \\
(2009)\end{array}$ & $\begin{array}{l}\text { Reyes and } \\
\text { Giaghetti } \\
\text { (2010 }\end{array}$ \\
\hline Costs & Yes & Yes & Yes & Not & Yes & Not & Not \\
\hline Colaboration & Yes & Yes & Yes & Yes & Yes & Yes & Yes \\
\hline Customers & Yes & Not & Yes & Not & Not & Yes & Yes \\
\hline Environment & Not & Not & Yes & Not & Yes & Not & Not \\
\hline Processes & Yes & Yes & Yes & Yes & Not & Yes & Yes \\
\hline $\begin{array}{l}\text { Performance } \\
\text { Measurement }\end{array}$ & Not & Not & Yes & Yes & Not & Yes & Yes \\
\hline Management & Yes & Yes & Yes & Yes & Yes & Yes & Yes \\
\hline $\begin{array}{l}\text { Technology and } \\
\text { Tools }\end{array}$ & Yes & Yes & Yes & Yes & Not & Yes & Yes \\
\hline Responsiveness & Yes & Not & Not & Yes & Yes & Yes & Not \\
\hline Strategic Focus & Yes & Yes & Yes & Yes & Not & Yes & Not \\
\hline Resources & Not & Not & Not & Not & Yes & Not & Yes \\
\hline
\end{tabular}

Based on the maturity models analyzed on the literature and shown in the Table 1 eleven dimensions of SCM maturity could be grouped and identified. As presented on the Table 2, Lockamy and MacCormak (2004) is most 
complete framework. Dimensions proposed by other authors present in Table 2 and not proposed by Lockamy and McCormark (2004) were included to form the theoretical framework. The eleven dimensions identified are: Costs, Customers, Processes, Technologies and Tools, Collaboration, Management, Performance Measurement, Strategic Focus, Responsiveness, Resources, and Environment.

The SCM maturity dimensions characteristics for each level of maturity are described below:

-Initial: prevalence of high costs, lower customer satisfaction, disintegrated and unstructured processes, lack of collaboration between members, lack of technologies and tools for forecasting demand and other activities, lack of strategic focus in the chain, poor management of supply chain projects, absence of risk management, lack of performance measurement in the entire supply the chain, lack of regulation and lines of credit as supporting elements, and use of basic resources.

-Intermediate: existence of cost savings in the chain, good customer satisfaction, documented and defined beginning of a cross-functional way of the processes in the entire chain, spirit of cooperation between the functions related to supply chain management in the focal company, use of technologies and statistical tools for forecasting demand and other activities, strategic focus, awareness, collaborators' vision and competence in supply chain management, good project management practices, limited use of risk management, evidence of performance measurement, existence of regulations and credit lines to support the supply chain, and use of adequate resources.

Table 3. Explanation for each maturity dimention for SCM

\begin{tabular}{|c|c|}
\hline $\begin{array}{c}\text { Maturity } \\
\text { Dimensions }\end{array}$ & Dimensions Meaning \\
\hline Costs & $\begin{array}{c}\text { Related to the costs incurred on SCM as inventory level, transportation costs, storage and handling } \\
\text { and others. }\end{array}$ \\
\hline Colaboration & $\begin{array}{c}\text { It is linked to share of earnings, resources, information, communication, initiatives, projects, product } \\
\text { develop and others among members of the supply chain }\end{array}$ \\
\hline Customers & $\begin{array}{c}\text { focus given to the customers by the focus company and members of the supply chain and te level of } \\
\text { customers satisfaction }\end{array}$ \\
\hline Environment & $\begin{array}{c}\text { Consider regulatory issues and credit incentives which can facilitate and improve the supply chain } \\
\text { performance }\end{array}$ \\
\hline Processes & It means Integration, formalization and structuring of the business processes along the supply chain \\
\hline $\begin{array}{l}\text { Performance } \\
\text { Measurement }\end{array}$ & $\begin{array}{c}\text { Refers to the performance measurement systems used on supply chain management, its } \\
\text { comprehensiveness and set of indicators }\end{array}$ \\
\hline Management & $\begin{array}{c}\text { Use project management method and standards for supply chain projects shared between members of } \\
\text { the chain, adoption of systematic supply chain, risk management and level of awareness and } \\
\text { training of supply chain management between the members of chain }\end{array}$ \\
\hline $\begin{array}{l}\text { Technology and } \\
\text { Tools }\end{array}$ & Use information technologies and tools to support supply chain management processes. \\
\hline Responsiveness & $\begin{array}{c}\text { Related to the ability of supply chain to attend environmental changes in terms of demand with } \\
\text { velocity and reliability }\end{array}$ \\
\hline Strategic Focus & $\begin{array}{c}\text { Is related to the strategic focus given by the members of the chain and the strategic goals deployed } \\
\text { among them }\end{array}$ \\
\hline Resources & $\begin{array}{c}\text { Refers to the common and competitive resources used to run the supply chain processes such as } \\
\text { facilities, equipment, machines, people, systems among others. }\end{array}$ \\
\hline
\end{tabular}

-Advanced: supply chain with cost excellence, total focus on customer satisfaction, fully integrated and structured processes in the entire chain, extensive use of information systems, profit and information sharing and colaboration between the supply chain members, project and risk management excellence, comprehensive performance measurement, supply chain as source of competitiveness, supply chain responsiveness dealing with variations of customers demand, extensive regulation, and credit lines to support the supply chain.

The explanation of each maturity dimension is described by Table 3 .

Based on the dimensions characteristics and level of maturity dimensions described, a theoretical proposition was developed forming the constructs to guide the case study method application. This will help to answer the research question which orientates this study.

Theoretical Proposition: The evolution of SCM occurs from an initial level to an advanced level in terms of costs, customers, processes, technology and tools, collaboration, management, performance measurement, strategic focus, responsiveness, resources, and environment. 
It is possible to note that the evolution of SCM maturity dimensions from initial stage to advanced stage becomes SCM more capable and creates a better integration over the chain, as showed in the Figure 1. Important to emphasize that the proposition stated above can be used to guide a field research and verify if it can be corroborated or not. This will help to answer the research question that orientates this study.

\section{Research Method}

The research design deals with the choices made about the research approach and research method. The qualitative approach was more suitable to guide the development of empirical research because it is flexible and focuses on practitioners' perspectives. The study of the SCM maturity requires the presence of a researcher in the field to clarify very complex constructs.

Case study can be used for the follow purposes: exploratory studies, theory build, theory tests, refining and extension (Voss; Tsikriktsis \& Frohlich, 2002).

Following this rationale, the multiple-case study was chosen as the most suitable research method and was conducted using a semi-structured interview as the research technique and a research protocol as the guide. The use of research protocol provides a more rigorous research, mainly researches related to SCM (Seuring, 2008; Yin, 1994).

The analysis unit was the supply chain focal company. Indeed, such companies should present different levels of maturity for an appropriate analysis. Three companies were chosen based on that criterion. The interviewees were supply chain managers and directors, who were in charge of downstream and upstream flows of supply chain.

The first company (A) is a of a US subsidiary. It operates in the metallurgical sector and is located in the State of Sao Paulo, Brazil. Its main customers are from companies in the automotive sector and its main suppliers are companies in the metal-mechanic and chemical industry sectors. The supply chain general manager is responsible for purchasing, production planning and, control, and handling and distribution within the supply chain. The second company (B) is also a US subsidiary. It operates in the pharmaceutical and human nutrition sectors. It is also located in the State of Sao Paulo. Its main customers are drugstores and supermarkets. Its major suppliers are food and chemical industries. The supply chain general director is responsible for purchasing, production planning and, control, and handling and distribution within the supply chain. The third company (C) is a US subsidiary operating in a chemical sector. This subsidiary is located in the State of São Paulo, Brazil and their main customers are concentrated on the automotive, construction and metal-mechanic sectors. As suppliers the main ones are also from chemical sector.

\section{Empirical Findings}

The semi-structured interviews were carried out following the research protocol. The foundation for developing the research protocol was the theoretical framework illustrated in Figure 1. The characteristics of the dimensions of the three companies for each dimension of SCM maturity are described in Table 4.

As shown in Table 4, the dimensions collaboration, technology, management, responsiveness, resources, environment, costs, and customers of Company A are in the initial level of maturity. The dimensions processes, measurement, and strategic focus are in the intermediate level of maturity. The maturity level of the SCM of Company A is initial since the number of dimensions in this level is greater than the intermediate level.

With regard to Company B, the evidences lead to a different interpretation. According to the evidences in Table 4, the dimensions of SCM maturity as management, technology, collaboration, processes, customers, costs, strategic focus, resources, and environment, are in the advanced level. Only the dimensions of responsiveness and performance measurement are in the intermediate level. Following the same criterion applied to classify Company A, the maturity level of the SCM of Company B is advanced.

For the Company $\mathrm{C}$, according to evidences presented in the Table 4 only 4 dimensions (customers, processes, strategic focus) are in advanced level. The other ones as costs, environment, resources, responsiveness, technology, measurement and collaboration were aligned with the intermediate level. Following the same criteria as the other first two companies to classify them in a maturity level, the Company $\mathrm{C}$ is presented on the intermediate level 
Table 4. Empirical findings for SCM maturity

\begin{tabular}{|c|c|c|c|}
\hline Dimensions & Company A & Company B & Company C \\
\hline Costs & $\begin{array}{l}\text { High costs and strong } \\
\text { pressure for cost reduction }\end{array}$ & $\begin{array}{l}\text { Cost excellence. Most of cost } \\
\text { reduction opportunities had } \\
\text { already been explored }\end{array}$ & $\begin{array}{l}\text { Pressure for cost reduction. Cost } \\
\text { reduction has been practiced } \\
\text { although it can be improved }\end{array}$ \\
\hline Customers & $\begin{array}{l}\text { Lack of customer } \\
\text { relationship practices and } \\
\text { focus on the customers }\end{array}$ & $\begin{array}{l}\text { Focus on customers in terms of } \\
\text { strong partnership. High } \\
\text { satisfaction index }(95 \%)\end{array}$ & $\begin{array}{l}\text { Focus on customers for each market } \\
\text { segment. High satisfaction index } \\
\text { (More than 95\%) }\end{array}$ \\
\hline Processes & $\begin{array}{l}\text { Some processes are } \\
\text { formalized and structured. } \\
\text { Internal integration }\end{array}$ & $\begin{array}{l}\text { Processes defined and } \\
\text { formalized. Integration with } \\
\text { Electronic Data Interchange } \\
(\text { EDI) }\end{array}$ & $\begin{array}{l}\text { Processes defined and formalized. } \\
\text { Integration using an Electronic } \\
\text { Data Interchange (EDI) }\end{array}$ \\
\hline $\begin{array}{l}\text { Technologies and } \\
\text { Tools }\end{array}$ & $\begin{array}{l}\text { Integrated management } \\
\text { system used. However no } \\
\text { application of intelligence } \\
\text { tools were observed }\end{array}$ & $\begin{array}{l}\text { Integrated Management System } \\
(\text { SAP }) \text {. Use of intelligence tools } \\
\text { such as Advanced Planner and } \\
\text { Optimizer Z(Apo) and Route } \\
\text { Planner. }\end{array}$ & $\begin{array}{l}\text { Integrated Management System } \\
(\text { SAP }) . \text { Lack of Intelligence tools to } \\
\text { support the SCM }\end{array}$ \\
\hline Collaboration & $\begin{array}{l}\text { No collaboration in terms of } \\
\text { gains and information share }\end{array}$ & $\begin{array}{l}\text { Share of information with } \\
\text { customers. Gains are shared } \\
\text { with distributors and suppliers. }\end{array}$ & $\begin{array}{l}\text { Partial share of information and } \\
\text { gains in the chain. It occurs only in } \\
\text { the downstream chain }\end{array}$ \\
\hline Management & $\begin{array}{l}\text { Project management and } \\
\text { risk management in supply } \\
\text { chain are not observed }\end{array}$ & $\begin{array}{l}\text { Use of Project Management } \\
\text { Book for project management. } \\
\text { Contingency plans for risk } \\
\text { management }\end{array}$ & $\begin{array}{l}\text { Project Management aligned to the } \\
\text { Six Sigma programs. Contingency } \\
\text { plans very well structured }\end{array}$ \\
\hline $\begin{array}{l}\text { Performance } \\
\text { Measurement }\end{array}$ & $\begin{array}{l}\text { Focus on financial } \\
\text { measurement with few } \\
\text { non-financial measures }\end{array}$ & $\begin{array}{l}\text { Focus on financial } \\
\text { measurement. Processes are } \\
\text { measured but not } \\
\text { comprehensively }\end{array}$ & $\begin{array}{l}\text { Focus on financial measurement. } \\
\text { There are few non-financial } \\
\text { indicator }\end{array}$ \\
\hline Strategic Focus & $\begin{array}{l}\text { SCM as important element } \\
\text { in the focal- company } \\
\text { strategy }\end{array}$ & $\begin{array}{l}\text { Very well defined strategic focus } \\
\text { Aim to achieve the best in class } \\
\text { status in SCM }\end{array}$ & $\begin{array}{l}\text { Very well defined strategic focus. } \\
\text { Aim to achieve excellence in SCM }\end{array}$ \\
\hline Responsiveness & $\begin{array}{l}\text { Low responsiveness } \\
\text { regarding to delivery of mix } \\
\text { of products }\end{array}$ & $\begin{array}{l}\text { Dimension requires } \\
\text { improvement. Supply Chain } \\
\text { requires a reasonable inventory } \\
\text { to respond to the market } \\
\text { demands. }\end{array}$ & $\begin{array}{l}\text { Requires improvement mainly in } \\
\text { the Upstream Chain to achieve } \\
\text { better responsiveness }\end{array}$ \\
\hline Resources & $\begin{array}{l}\text { There is no differentiation of } \\
\text { resources used in the SCM }\end{array}$ & $\begin{array}{l}\text { Advanced centers to develop } \\
\text { differentiated products }\end{array}$ & $\begin{array}{l}\text { Adequate resources in the chain } \\
\text { although more technologies need to } \\
\text { be implemented }\end{array}$ \\
\hline Environment & $\begin{array}{l}\text { There are no incentives } \\
\text { regarding importation of } \\
\text { products causing difficulties } \\
\text { related to competitiveness }\end{array}$ & $\begin{array}{l}\text { Existence of regulations } \\
\text { regarding competition issues in } \\
\text { the market. }\end{array}$ & $\begin{array}{l}\text { Incentives linked to importation } \\
\text { taxes has been recently implemented } \\
\text { facilitating competition }\end{array}$ \\
\hline
\end{tabular}

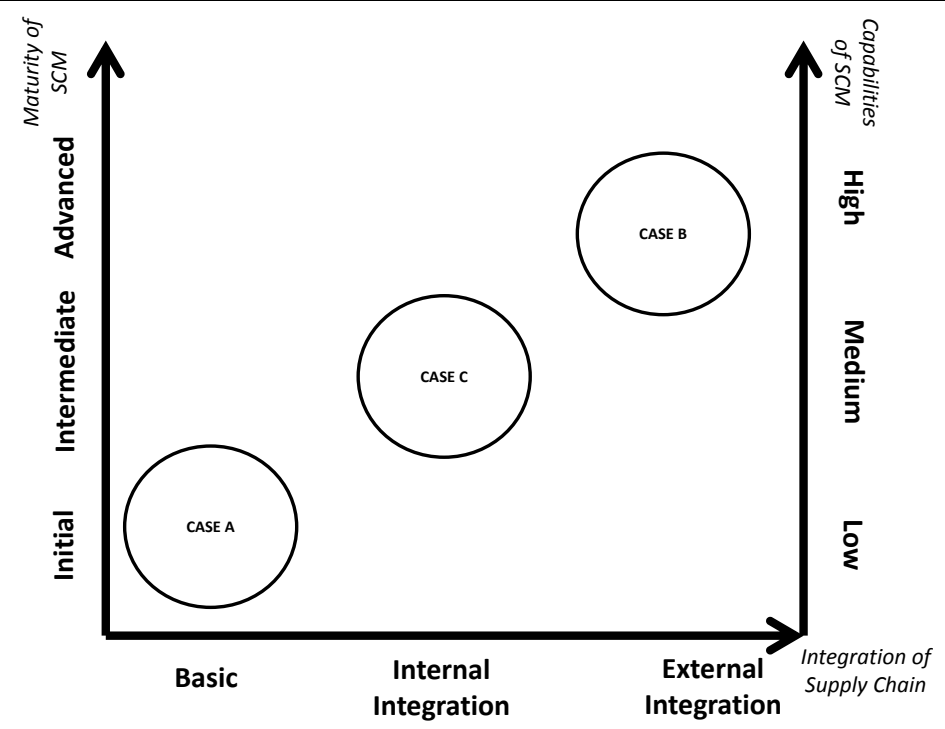

Figure 2. Evolution of SCM Maturity Dimensions 
Figure 2 synthetizes the findings from case studies applied. It shows that the Company A that is on initial level of maturity has not integration in its supply chain and low set of capabilities.

In case of Company $\mathrm{C}$ it is intermediate level in terms of SCM maturity having a medium set of capabilities and internal integration. Lastly, Company B has advanced level of maturity being high integrated in supply chain with higher set of capabilities. These evidences captured from empirical research area aligned with the theoretical proposition established to guide this research purpose.

\section{Final Remarks}

This paper aimed to present a robust theoretical model of maturity of SCM. This approach has an important relevance taking into consideration the different proposals for SCM maturity in the literature considering different dimensions. Aiming to achieve this purpose, an extensive literature review was done using a systematic approach which allows a better reliability and quality of the data obtained. A qualitative approach using a multiple-case study was adopted considering that this study aims to explore the subject proposed and generate a contribution to the literature as basis for future qualitative and quantitative researches.

As the main findings it was possible to identify eleven dimensions which drive the maturity of SCM as stated in the theoretical proposition and asked on the research question stated. Those dimensions are showed in Figure 1. Important to emphasize that the maturity models present on the literature for SCM don't consider all dimensions needed, reason why a theoretical model was built taking into considerations all dimensions proposed by different authors.

Evidences found out from empirical research could confirm the eleven dimensions proposed. The data gathered and analyzed show that the maturity of each dimension can be in different levels for the same company. In this study, aiming to classify the company in a determined level of maturity was adopted as a criteria the level which the most of dimensions are classified in. However, is necessary a better understand on this aspect in order to understand what are the relevant dimensions to classify a level of maturity and also to understand the relationship between these dimensions of SCM maturity. Other aspect to be considered is related to importance of each dimension for different segment of business. It is required to deploy this research for different kind of supply chains to have a better view about level of importance of the dimensions for each type of chain. Lastly, a deep understand about practices in SCM becomes important once are these practices that will in fact support each dimension of maturity.

The following research questions needs to be answered to the evolution and more cleare about maturity in supply chain management.

- What are the relevant dimensions to determine the exact level of SCM maturity?

- What is the relationship between the SCM maturity dimensions?

- Are the eleven dimensions identified enough to drive the maturity of SCM for all type of supply chains?

- Which dimensions are relevant and crucial for specifics supply chains?

- Which practices of SCM can be adopted to support each dimension of maturity?

The findings from this research bring up an important contribution for the theory related to SCM. Also, it can be a reference guide to help practitioners to seek a better alignment in terms of dimensions of SCM to be prioritized to get more level of integration and performance.

\section{References}

Ayers, J., \& Malmberg, D. (2002). Supply Chain Systems: Are You Ready? Information Strategy: The Executive's Journal. Retrieved from http://ayers-consulting.com/download/SC\%20Systems\%20-\%20Are\%20You\%20Ready.pdf

Ayree, G., Naim, M., \& Lalwani, C., (2008). Supply Chain Integration Using a Maturity Scale. Journal of Manufacturing Technology Management, 19(5), 559-575. http://dx.doi.org/10.1108/17410380810877258

Beamon, B. (1999). Measuring Supply Chain Performance. International Journal of Operations \& Production Management, 19(3), 275-292. http://dx.doi.org/10.1108/01443579910249714

Chan, F., Qi, H., Chan, H., \& Lau, H. I. P. R. (2003). A Conceptual Model of Performance Measurement for Supply Chains. Management Decision, 41(7), 635-642. http://dx.doi.org/10.1108/00251740310495568

Childerhouse, P., Deakins, E., Bohme, T., Towill, D., Disney, S., \& Banomyong, R. (2011). Supply Chain Integration: An International Comparison of Maturity. Asia Pacific Journal of Marketing and Logistics, 


\section{3(4), 531-552. http://dx.doi.org/10.1108/13555851111165075}

Christopher, M. (2005). Logistics and Supply Chain Management. 3rd ed. London: Pearson Education.

Daozhi, Z., Liang, Z., Xin, L., \& Jianyong, S. (2006). A New Supply Chain Maturity Model With 3-Dimension Perspective. ITIC - Proceedings of Information Technology and Innovation Conference, Hangzhou. https://doi.org/10.1049/cp:20061046

Dellana, S. A., \& Kros, J. F. (2013). An Exploration of Quality Management Practices, Perceptions and Program Maturity in the Supply Chain. International Journal of Operations \& Production Management, 34(6), 786-806. http://dx.doi.org/10.1108/IJOPM-03-2013-0105

Geary, S., \& Zonnenberg, J. (2000). What it Means To Be Best in Class. Supply Chain Management Review, Jan/Aug, 43-48.

Gunasekaran, A., Patel, C., \& Tirtiroglu, E. (2001). Performance Measures and Metrics in a Supply Chain Environment. International Journal of Operations \& Production Management, 21(1), 71-87. http://dx.doi.org/10.1108/01443570110358468

Harter, D., Krishnan, M., \& Slaughter, S., (2000). Effects of Process Maturity on Quality, Cycle time, and Effort in Software Product Development. Management Science, 46(4), 451-466. http://dx.doi.org/10.1287/mnsc.46.4.451.12056

Huang, Y., \& Handfield, R. (2015). Measuring The Benefits of ERP on Supply Management Maturity Model: A "Big Data" Method. International Journal of Operations \& Production Management, 35(1), 2-25. http://dx.doi.org/10.1108/IJOPM-07-2013-0341

Kwak, Y., \& Ibbs, W. (2002). Project Management Process Maturity Model. Journal of Management In Engineering, 18(3), 150-155. http://dx.doi.org/10.1061/(ASCE)0742-597X(2002)18:3(150)

Lambert, D., \& Cooper, M. (2000). Issues in Supply Chain Management. Industrial Marketing Management, 29, 65-83. http://dx.doi.org/10.1016/S0019-8501(99)00113-3

Lockamy, A., \& McCormak, K. (2004). The Development of a Supply Chain Management Process Maturity Model Using the Concepts of Business Process Orientation. Supply Chain Management: An International Journal, 9(4), 272-278. http://dx.doi.org/10.1108/13598540410550019

McCormak, K., Ladeira, M. B., \& Oliveira, M. P. V. (2008). Supply Chain Maturity and Performance in Brazil. Supply Chain Management: An International Journal, 13(4), 272-282. http://dx.doi.org/10.1108/13598540810882161

Netland, T., \& Alfnes, E. (2011). Proposing a Quick Best Practice Maturity Test for Supply Chain Operations. Measuring Business Excelence, 15(1), 66-76. http://dx.doi.org/10.1108/13683041111113259

Okongwu, U., Morimoto, R., \& Lauras, M. (2013). The Maturity of Supply Chain Sustainability Disclosure From a Continuous Improvement Perspective. International Journal of Productivity and Performance Management, 62(8), 827-855. http://dx.doi.org/10.1108/IJPPM-02-2013-0032

Oliveira, De, M. (2009). Modelo de Maturidade de Processos em Cadeias de Suprimentos: Precedencias e os Pontos-Chave de Transicao, Tese (Doutorado em Administração) Programa de Pos-Graduacao em Administracao, UFMG, Belo Horizonte. Retrieved from http://www.bibliotecadigital.ufmg.br/dspace/handle/1843/BUBD-9BEJT8

Oxford. (2011). Oxford Dictionaries. Oxford University Press.

Performance Measurement Group - PMG - PRTM. (2007). Competitive Advantage of Best in Class Supply Chains. Pennsylvania. Retrieved from

http://www.pmgbenchmarking.com/public/survey/dvantagesofbic.Pdf

Pires, S. (2009). Gestao da Cadeia de Suprimentos: Conceitos, Estrategias, Praticas e Casos, 2nd. Sao Paulo: Atlas.

Reyes, H. G., \& Giaghetti, R. (2010). Using Experts to Develop a Supply Chain Maturity Model in Mexico. Supply Chain Management: An International Journal, 15(6), 415-424. http://dx.doi.org/10.1108/13598541011080400

Seuring, S. (2008). Assessing the Rigor of Case Study Research in Supply Chain Management. Supply Chain Management: An International Journal, 13(2), 128-137. http://dx.doi.org/10.1108/13598540810860967

Seuring, S., \& Gold, S. (2011). Conducting Content-Analysis Based on Literature Reviews in Supply Chain 
Management. Supply Chain Management: An International Journal, 16(5), 544-555. http://dx.doi.org/101108/13598541211258609

Simchi-Levi, D., Kaminsky, P., \& Simchi-Levi, E. (2003). Introduction to supply chain management. In: Simchi-Levi, D.; Kaminsky, P.; Simchi-Levi, E. Designing and managing the supply chain: concepts, strategies and case studies. 2nd ed., Boston: McGraw-Hill.

Souza, R. P., Guerreiro, R., \& Oliveira, M. P. V. (2015). Relationship Between the Maturity of Supply Chain Process Management and the Organisational Life Cycle. Business Process Management Journal, 21(3). http://dx.doi.org/10.1108/BPMJ-03-2014-0023

Stevens, G. (1989). Integrating the supply chain. International Journal of Physical Distribution \& Logistics Management, 19(8), 3-8. http://dx.doi.org/10.1108/EUM0000000000329

Tranfield, D., Denyer, D., Palminder, S., (2003). Towards a Metodology for Developing Evidence-Informed Management Knowledge by Means of Systematic Review. British Journal of Management, 14, $207-222$. http://dx.doi.org/10.1111/1467-8551.00375

Van Aken, E., Lettens, G., Coleman, G., Farris, J., \& Van Goubergen, D. (2005). Assessing Maturity and Effectiveness of Enterprise Performance Measurement Systems. International Journal of Productivity and Performance Management, 54(5/6), 400-418. http://dx.doi.org/10.1108/17410400510604557

Venkatraman, N., \& Henderson, J. (1998). Real Strategies for Virtual Organizing. Sloan Management Review, 40(1), 33-48, Fall.

Voss, C., Tsikriktsis, N., \& Frohlich, M., (2002). Case Research in Operations Management. International Journal of Operations \& Production Management, 22(2), 195-219. http://dx.doi.org/10.1108/01443570210414329

Wettstein, T., \& Kueng, P. (2002). A Maturity Model for Performance Measurement Systems. Management Information Systems, 113-122.

Yin, R. (1994). Case study research: design and methods, Sage Publications, Newbury Park.

\section{Copyrights}

Copyright for this article is retained by the author(s), with first publication rights granted to the journal.

This is an open-access article distributed under the terms and conditions of the Creative Commons Attribution license (http://creativecommons.org/licenses/by/4.0/). 